\title{
Violations of water rights, socio-ecological destruction and injustice in Turkey by hydro-electric power plants
}

\author{
G. Öztunalı Kayır \\ Akdeniz University, Turkey
}

\begin{abstract}
Water is an essential part of any ecosystem, and reduced water quantity and quality both have serious negative impacts on the ecosystems; on health as on human rights.

The UN Human Rights Fact Sheet No. 35 about water rights is our basic document. General Commentary No. 15 of the Committee on Economic, Social and Cultural Rights accepts within the perspective of social rights that water rights are in an inseparable relationship with the right to live, adequate nutrition, the right to health, housing right and human dignity. 41 countries, including Turkey, express reservations on the decision taken by the UN in 2010 that acknowledges water and public hygiene as a human right.

In this study, on the basis of the main principle "Water is the right of nature; water is the right of all living creatures" it is explored how the constructions of a great number of hydro-electric power plants resulting in social-ecological destruction and injustice take away local people's and vulnerable groups' water rights and right to live. The hydro-electric power plants, water transfer schemes which violate water rights in Turkey in collaboration with the private sectors, are analyzed from the point of social-ecological rights. Giving the examples of countries which have water rights in their constitutions, the necessity to regulate water rights in the Turkish Constitution for the purpose of protecting collective social-ecological rights of water is presented.
\end{abstract}

Keywords: water rights, hydro-electric power plants, hydro-electric plants struggle, social-ecological destruction, constitutional regulation. 


\section{Introduction}

The oldest tree in the World is 9550 years old and stands in Sweden, a 1700year-old monument cedar wood is still alive in Antalya-Alakır but we are unaware of this natural order and wealth. What we are doing? We are preparing the death warrant for water, soil, rivers, lakes, oceans, insects, fish, birds, bees and people. History has shown us that the water always flows in its own way; it is always protected and it cannot be turned to be a possession because of its importance, it persists to be public.

On the purpose of social and ideological auto-legalizations, the government uses water as a strategic tool by developing headwaters and founding irrigation channels, dams and hydro-electric power plants (HEPP), and this is a very common situation in developing countries [1]. The biggest danger is that because of this mentality that turns the water into a prosperity, the exchange value of water may head off its usage value. On the other hand, the most effective power is the cultural-ecological integrity and the local communities who are part of this integrity. In this context, the aim of this paper is to reveal how Turkey's HEPP projects create irreversible problems while having an eye on the water rights of all living beings. It also aims to show the socio-ecological destruction of a growing number of hydroelectric plants and the violations of water rights.

\section{Violations of water and socio-economic rights}

Water is the right of nature and all living creatures. And water is also the right of human beings.

a) Water is the fundamental and basic factor in the lifetime of all living beings, and it's a part of inalienable rights.

b) In terms of human rights, water is an essential right for human dignity and it's the precondition of providing the other human rights.

c) Water is also a part of the right to live, right to health, right to food, right to housing and environmental right.

d) In terms of struggling with the HEPP, water is a collective right.

It is stated in the documents that the right to water took place as a human right for the first time in the Mar Del Plata Conference (1977). But at the end of the Rio Summit (1992), the "Dublin Report of Water and Sustainable Development" was published and in the fourth Dublin principle there is an assertion: "Water has economic value in every kind of usage area and it should be seen as an economical Meta." According to this assertion, water supply systems, such as other essential possessions and services, can be operated in market conditions [2]. According to Article 3 of 2002 UN (United Nations) General Comment No. 15: "water right is inseparably linked with adequate nutrition and housing rights". With concepts like right for living, right for health and honor of humanity as a precedence of implementing human rights, water right is discussed within the framework of human rights and social rights. The UN identified water rights within the framework of four basic principles: a) being adequate of water (availability); b) having appropriate quality (quality); 
c) being accessible (accessibility) and d) equal access, minding people who are at low levels in terms of socio economic perspectives (equal access). The UN approach to water in terms of human rights and social rights, accessibility to clean and cheap water is accepted as a basic human right. Governments and other actors are obliged to enable realization of this right. Contracting states also have international responsibilities and it is declared that polluting water sources and practices to reduce water that may affect the use of water rights in other countries must be avoided. Water right is handled as a prerequisite for realizing other human rights [3].

The Rio+20 (2012) Summit was far beyond Dublin and with the Natural Capital Declaration by 40 international financial organizations air, water, soil, flora, fauna including areas under protection became market instruments for financial institutions. As a result of this neoliberal understanding, with HEPP constructions that have been the basic means of government, socio ecological destructions and violations of water rights has been lived with great pains. HEPP that are practiced with neoliberal policies, with the desires for capital accumulations continues in the forms of occupations, pillage and plunder, ecological destruction, right violations and dispossession by changing within the process. Our country also was regarded as one of the countries to be affected by the food crisis but even if it remains being one of the country's lowest risks, the negative results of climate changes have begun to be lived. Especially for those living in rural areas, farmers and poor people living in cities are reported in the aforementioned report to be the ones "that would be mostly affected by food shortage" [4].

The UN accepted clean and healthy water as basic life and human rights B.M. 2010. They determined principles related with water and health rights and hold governments responsible from taking positive precautions, providing concrete equality about water and preventing poor individuals and groups from being discriminated against $[5,6]$.

The UN identified water and sanitation rights as human rights with its General Assembly Decision. 122 country gave a vote for this decision. 41 countries including Turkey, the USA, Sweden, Israel, Japan, and England abstained. Turkey declared at the UN General Assembly meeting dated July 2010 that Turkey was chary of decision $[7,8]$.

Another different approach with Kurt's [9] suggestion, mentioning that in the context of struggle with HEPP, the fight for water rights must be handled with collective ecological demands and collective rights. It would not be wrong to call for collective right concept in terms of struggle with hydroelectric power stations. Conceptualization of a labor based collective right understanding would be useful - both to understand the process and think about possibilities of it as far as it considers ecological demands.

A UN High Commissioner Report, declared in the meeting about environment in 2011 by the Human Rights Council suggests that reducing the quality of water, destruction of water resources, environmental problems directly affect human rights [10].

The struggle in 2000 against government for the privatization of water in contrast to all serious human deaths, caused the start of movements for water 
justice and, as a result of the surrendering of the Bolivian Government, water companies left the country. Water being a basic human right and with the acceleration of social movements about water in many countries against the declaration of Ministers in the World Water Forum, held in İstanbul in 2009. With a referendum in Uruguay in 2004 about opposing regarding water as "basic human right", 26 countries signed an agreement that supports water as a human right and invalidating privatization of water in Italy in 2011 and price determination freedom for water distribution companies. The decision saying that the "UN General Assembly recognizes accessibility to safe and secure water and sanitation required for benefiting from life and human rights to the end as a basic human right". This is a result of water right and justice struggles. On the other hand, within the framework of Environment Justice "fair acts" means not forcing anyone due to economic and politic shortages to be subject to living with the non-proportional effect of pollution [11].

The biggest five HEPP are in Karaman-Ermenek. The city which owns historical and cultural assets provided living space, in particular to the Hittite Civilization dates back to before Christ 3000, Achaeans, Babels, Hellenic and Rome. Headmen of the village complains that "This place meets the need of vegetables and fruits, our villagers do not know the way apart from farming. In 2005 , in which it was given a start for expropriation, we were bid to sell in unreasonable amounts. We used to earn the offered money in that lands in the period of 2-3 years. Now, the lands are in flood. Many people had to move into different cities. It is impossible for villagers to buy lands which is the same conditions in district" [12].

Antalya-Alakır, the city where I lived, is faced with the destruction of 28 villages by 8 HEPP. Alakir valley is a place to be protected with its biological diversity, countless flora and fauna, ecological richness and cultural and social life. Ancient Likya cities, seven of which are in the valley, have old water mills and old wooden bridges, Cedar Forests, the monument cedar tree at the age of 1700 (Ambar Katran1), (salmo trutta), (Platanus orientalis), Ilgin (Tamarix sp.), Mersin (Myrtus communis), Funda (Erica sp.) oak types (Quercus coccifera, Quercus brantii), Caucasian hackberry (Celtis caucasica), lemurs, red pines (Pinus brutia), Cedar (Cedrus libani) and Junipers (Juniperus foetidissima, Juniperus excelsa) are just some of them. Mountain goat, deer, boar, rabbit, partridges, curlews and snakes are the main animal species. One part of the Alakir region is a protected area at the first level and in this river Salmo trutta macrostigma, which are at critical levels for stocks in our country, lives and for the continuation of its generation it is scientifically suggested that streambeds of Alakır rivers and streams of Köprüçay, Değirmenözü and Başpınar must be strictly protected. The "good and service circulation of people who live, produce and feed the country in Alakır streambed may not be disregarded... the right for life of people, their productions and the trade system created by them, public security, nutrition of society are included in "high public benefit" $[13,14]$.

Countries such as Belgium, Portugal, Bolivia and Uruguay which have water rights in their constitutions, number about 30 in the world, who also provide the 
right to health care, adequate food, water and social security. This is so far for our country.

\section{Increase in the numbers of HEPPs and its results}

The existing government in Turkey since 2002 privatized water and left rivers to dry up and directed towards capital by enriching private companies by disregarding the participation of people to government, including of people to water management by combining the knowledge of experts and local people, having the direct word of people on the subject about their own environment and life areas. Regulation on water usage was put into force by being published in Official Gazette [15].

Privatization of water means the destruction of a countless number of laws and regulations for the health of people, nutrition and ecological values in Turkey. The government changed all laws about agriculture, livestock, meadows, mines and environmental laws during its sovereignty and people have been left dispossessed.

Turkey has 26 streambeds. The gross surface water potential of Turkey is 193 milliard cubic meters, but usable water potential is 14 milliard cubic meters, although $35 \%$ of Turkish people are on the edge of water poverty [16].

The General Directorate of State Hydraulic Works declared not to build any more dams and HEPP would be built only by private sector, almost 3500 dams and HEPPs are planned to be constructed. According to 2013 year end data, Turkey's total HEPP power is almost 22 thousand MW and 10 thousand MW additional capacity is planned [17].

Turkey, the second country where electricity demand has increased most after China, used 245 billion $\mathrm{kw} / \mathrm{h}$ electricity and became the fifteenth in terms of using electricity all around the world. The Turkish Parliamentary Record, according to the data, electricity use increased $1.3 \%$ in 2013 compared to the year before, and resulted in 245.4 billion kilowatt. But, HEPP will enable almost $5 \%$ electricity all around Turkey $[18,19]$.

\subsection{Companies make good profit}

Because of the relationship between capital and water in Turkey, streams, lakes, rivers are sold to the private sector by customizing and socialization and this causes private companies to act in a lawless and ruleless way. For instance, AKFEN Holding Company declared that they would build HEPP in Erzurum and Bayburt and increase their energy investments to 615 billion Euro [20].

Environmental engineer B. Üstün stated in a panel: "In 2010, 1800 companies made agreement on water right from the shortest stream to the longest river and now they are the owners... You cannot use the water of Mercan for $12 \mathrm{~km}$ and Erbağ for $63 \mathrm{~km}$ as they belong to the company. If this water does not flow, every piece of green area will disappear beginning from the top of this critical part. So, this ecosystem will turn into a desert. We thought only electricity would be produced in this area, but unfortunately this game is more tricky than we 
guessed, they are sell first of all their carbon licenses and in the second stage the valley area" [21].

\subsection{Socio-ecologic devastation}

According to the report of Parliamentary Researche Directorat (2014), the positive and negative features of HEPP are listed and given place to many important facts. For HEPP investment and obtaining, almost 6 billion dollars is needed in the next ten years. "There are also some critics related to EIA. It is thought that planning has not been made according to basin, and each project has been evaluated on its own, and as there are many different projects on the same basin, it would be more dangerous for the environment. Besides, it is claimed that the amount of sap is not sufficient for protecting river health and increasing this amount is up to the initiative of companies, different flow distributions are not taken into consideration and especially as the amount of water of HEPPs on the same basin have not been calculated according to total basin plans, it causes so much harm to the aquatic ecosystem" [22].

With the transitory article added to EIA regulations construction projects before the Environmental Effect Regulation had been approved in 2008. Until that time to the ones that got permission, license, approval or nationalization decision the inscription "provisions of regulation are not implemented" had been added.

\subsubsection{Technical expertise and deadlocks in terms of people's right to life and water}

We can list the basic real underlying reasons of HEPP causing reactions, and unequal, adequate application and unprincipled goings on of the government as follows:

$\checkmark$ Ignoring supremacy of law;

$\checkmark$ Turning normlessness into a norm;

$\checkmark$ Not questioning whether it is the need for energy, right of water or right of life;

$\checkmark$ Ignoring harm caused to the environment and natural life by going beyond the scope of EIA;

$\checkmark$ Diverging from the sense of saving natural and historical protection areas;

$\checkmark$ Watershed management principles and ignoring the holistic viewpoint;

$\checkmark$ Without having ecological concerns, turning national income, economic return and national resources into market goods, not considering its contribution to capital accumulation;

$\checkmark$ Not being very productive of HEPPs and producing less energy than planned;

$\checkmark$ Sustenance of the ideology Accumulate, Produce and Consume (APC) and capital value being more important than nature and human life;

$\checkmark$ Being used for most of the energy produced for 5-7 star hotels and lighting buildings and luxurious consumption,

$\checkmark$ Ignoring the needs, life and future of people of a region, removing villages and forcing people to migrate;

$\checkmark$ Concealing realities from people;

$\checkmark$ Using the violence of government on nature and people of the region. 
As it is mentioned in World Dams Commission Report (2000), although dams and HEPP have very important contributions to make towards the development of humanity, unacceptable prices are paid in terms of social and environmental issues. It is observed that HEPP in Turkey resulted in severe socio economic and ecological results. Although basic principles like (1) justice; (2) sustenance; (3) productivity; (4) participation and (5) responsibility in order to avoid the high social and environmental costs of damns in the event of giving a decision about water and energy issues, have not been taken into consideration in HEPP; also, especially, the principles emphasized by the commission as strategically priorities "getting approval of people, protecting the rivers and livelihood possibilities provided by them" are completely disregarded [23].

\subsubsection{Disregarding technical and ecological principles, irreversibly destroyed ecological and cultural values}

HEPP provide $5 \%$ of all electricity produced in Turkey, which are seen as renewable energies lose this feature when they are not considered on a holistic and reservoir basis. In EU countries, river type hydroelectric power plants are classified into renewable energy according to their installed capacity and according to this HEPP which have installed capacities to the level in Sweden 1.5 MW, in Germany 5MW in Spain and in England 10MW are classified into renewable energy class and therefore in our country it is observed that many of the constructed HEPP are not projects that can be classified into renewable energy class according to European standards. According to Turkish Electric Market License regulations, HEPP which have $20 \mathrm{MW}$ are categorized as renewable energy. This means more ecological destruction than the ones in European countries.

Some important emphasis from research, HEPP Commission of Chamber of Construction Engineers, shows socio-ecological disasters. All HEPP which were built after the Electricity Production of Renewable Energy Sources Related to the Use of Property Law entry came into force in 2005 were constructed without providing necessary conditions in an environment. These factors reduce the water regime, negatively affect fauna, flora and, as a result, human life around the river and many problems occur during construction in streambeds and the surrounding area and the ecosystem is drifting towards annihilation from which it does not return [24].

The deformation and losing control of the ecological system are important areas where negative sides are seen. As a result of breaking out of river links fishing was generally negatively affected. Local and regional climate changes increase the rate of humidity and change the precipitation index and as a result negatively affect plant and animal species and agriculture based on a culture of thousands years [25].

Some examples for HEPP were found in the provinces of Artvin, Bayburt, Giresun, Gümüşhane, Ordu, Rize, Trabzon and Erzurum that has 1500 plant species of which $70 \%$ are endemic and the life area for around 30 animal species and bird species. It is reported that the climate of the Eastern Black Sea was changed and flora fauna and bio diversity was destroyed. There are at least 2,675 endemic plants and biological richness, 2,460 vascular plant species, 300 of them 
(about 12\%) are endemic to Turkey. It is reported that around 160 species exist only in Northeast Anatolia and two of 18 natural oak species of Turkey grow here (Q. Aucheri and Q. vulcanica) and fauna like deer, roe deer, wild boar, brown bear, wild cats, and catamount, enters the migration area of migratory birds [26].

In an area in Firtina streambed that is very close to the National Park of Rize and Kaçkar Mountains (52,000 ha) a dam, 10 HEPP and 11 regulator construction in total 21 constructions were planned. Somehow, according to an EIA report, HEPP will not have any important damage on the environment. However, in a case opened by a group of people, Trabzon Administrative Court agreed that this report was not rightly evaluated by the Ministry and the EIA report was not comprehensive and the negative sides of the project were not truly discussed. As a result of court decision, construction was stopped but the Project was not completely cancelled. Protests still continue - due to socio-cultural and ecological destruction starting with large dams and continuing with HEPP [27].

"Turkish water politics have been reconfigured along the lines of neoliberalism. By doing so, it generates a form of exclusion where legal frameworks regulate in a way that land and water under the property of state and rural communities are reallocated, despite leading to serious ecological and social impacts. The ambiguous EIA processes, renewable energy laws allowing construction on reserved and protected areas and urgent expropriation decisions are illustrations of how the legal rights are negotiated in a way that favours private interest" [28].

HEPP causes taking precedence of financial profits over human rights, privatization of rivers, water services in poor countries, being destabilized life of local people and their life area under the name of "liberal economy" and exploitation of them.

\section{Contradictions with international agreements and playing tricks with national laws}

A parallel report was presented against the report presented by the government to the U.N. Committee and by expressing that "case studies from various regions of Turkey illustrate the deficits in the legal system and constitute severe violations of economic, social and cultural rights in themselves" realities were manifested. "General Comment No. 7 and the Basic Principles, General Comment No. 15 on water also puts great emphasis on the participation and consultation of the project affected population...the right to an adequate standard of living including the right to food, water and housing [29, 30].

On a national scale, although jurisdiction decides on the suspension of execution and cancellation, projects still continue. It is an action of unconstitutionality.

Although "Social State" concept takes place in the Constitution as a basic characteristic of the Turkish Republic, it is not possible to mention this feature of Turkey. With the construction of HEPP, the basic human rights of people, water 
rights for life, and collective rights since they are villages are taken out of their hands and they are left face to face with starvation, drought and poverty.

The Law on Expropriation No. 2942 regulates compensation levels for people who lose their assets due to an infrastructure project and it is far from being in line with General Comment No. 7 and the Basic Principles. It was amended with Settlement Law (Law No. 5543) was extracted and socio economic destructions accelerated and dispossessions were started to be implemented [31].

Law No. 5543, Article 121) A) Families who were forced to leave their areas due to partial or total expropriation of their real properties,

(3) The families that were effected with expropriation and settling in expropriated areas by state institutions and organizations but do not want settlement in another areas with hands of state, may be settled in another area within the borders of their own villages on condition that they receive the proposal of governorate and confirmation of Ministry of Internal Affairs upon their written application.

Law No. 5543, Article 27 (3) Debiting values for properties shall be obtained without any interest. Pursuant to this law, enterprise and equipment loans, installment sale of lands in order to regulate physical settlement and dwelling, enterprise credits given to families are subject to interest.

(6) In accordance with the provisions of this law, for the whole of settlement supports by means of indebting, in favor of a national treasure primary and firstly lien is established for real properties given.

Ambitions for controlling nature continues with privatizations. While water sources are exploited with supply based strategies financed with public and private budgets, underground waters are controlled by using up and polluting, the number of companies only seeking individual profits and gaining day by day due to many HEPP constructions on one river. Alakır Streambed, destruction of 28 villages by 8 HEPP.

HEPP struggles and cancellations in Turkey continue. According to the answer given to a written question for the Ministry of Environment and Urban Planning after two months (17.12.2013) since 2002 till that time in our country generally it was decided for 655 project in total that 274 HEPP EIA is positive but, for 2588 projects in total, 1082 HEPP it was decided not to be necessary. For 65 projects it was decided that cases still continue. It is a proof for the scope of destruction that half of HEPP projects that are essential to cause ecological destruction are decided not to require EIA [32].

There are reactions towards HEPP all over our country from the Mediterranean to Munzur; from Firtına Valley to Hasankeyf. Within this, there are structures that are organized in the form of platforms. Platform of Brotherhood of Rivers, Black Sea is in Rebellion, We won't Give Anatolia, Munzur Protection Assembly, Enterprise for Living Hasankeyf; are the most important ones.

Three EIA reports on HEPP in Alakir were cancelled but the construction was not cancelled (2012). 30,000 signatures were collected and delivered to the Ministry in 2014. 
The big HEPP struggles are carried by women. They provided their backoff by standing against police officers and gendarmes in their tents sometimes under snow in the cold, leaving their homes for days. They led for carrying a case and provided the cancellation and postponement of around 65 HEPP projects. They screamed for protecting their life area with more anger even than men. "The HEPP and dam licences which were provided without a basin plan and without the approval of local inhabitants should be cancelled. The ongoing projects which create social, cultural and ecological damage and which privatize the right to use the water should be stopped. Renewable energy resources (such as solar, wind, geothermal and wave power) and energy efficiency should be promoted in order to meet the energy demand" was noted in our declaration [33].

\section{Conclusion}

The present paper has documented a shift in the dominant and destructive political approach to water rights in many cities in Turkey. Projects of dehumanizing, dispossession, and impoverishment have made the life inhabitable with the HEPP constructions in a lot of cities in Turkey. Violations of water rights and the necessity to locate them in the Turkish constitution is primary.

Planning, construction and operation processes of HEPP in the technical sense are far from the law, scientific knowledge and principles of sustainability, and it is a fact that HEPPs pose a serious threat to our rivers. And today, very few streams remain in the natural flow and in their beds; most of them have started to get dry. The government accounting that the country's water would be further reduced in 2030s even as a result of the population growth should not be insistent on continuing to the projects causing the rivers drying. In the event of putting all HEPP into effect, it is inevitable that throughout the country our streams, rivers, their ecological cycles, and services they provide and biological diversity would be damaged significantly and it is a must to abandon HEPP and disregarding people's water right. The government must end HEPP violence.

Privatization of both the water services and basins, and constructing power plants on each river in the country, with the government's destructive land, water and energy policies cause the extinction of endemic species, prevention of fishing, destruction of historical and cultural assets, pollution, unfair share, administrative problems and, especially, decline in production in terms of the environment. Therefore, local communities and local governments having a oneto-one relationship with water, constitute the most competent and effective unit required to defend the water as they regard the water not just as a vital asset but also as an integral part of the culture. That the struggle shall continue could be considered definitive. Because it is a matter of life and war of future.

The government's approach which disregards that the growing injustice and socio-ecological destruction threaten the interests of the country has brought migration, rapid and unplanned urbanization, ecological destruction, violations of human rights, water rights and collective rights. While it is obvious that thousands of HEPP will lead to the rapid destruction of natural assets as water and soil, governments choosing to forget that water is not a commodity but a 
natural value, necessity and source of life are not only in Turkey. For this reason, the need for the urgent establishment of an alternative organization protecting and providing international water right is obvious. There has been no binding international agreement on water right yet despite the UN's resolutions. In order to make the water right binding in terms of countries, it is required to guarantee it with an international agreement. There is a need for contract that can lead to the protection of right to water against commodification and commercialization.

Water is the basic element of life; it is the right of nature and all living creatures, an inalienable human right that is part of the right to live, the reason for denying any kind of privatization, that the management and inspection of water shall be conducted by public, social, collective, participatory, fair, equitable and without intent to profit is a requirement of the democratic, social and lawful state.

\section{References}

[1] Saurí, D. and del Moral, L. 2001. Recent developments in Spanish water policy. Alternatives and conflicts at the end of the hydraulic age. Geoforum 32(3): 351-362.

[2] Topçu E., Water Right as a Human Right, Doctoral Thesis, Ankara Uni. Law Faculty, 2009.

[3] CESCR (Committee on Economic, Social and Cultural Rights): The Right to Water, General Comment No. 15 para 48 on the right to water, General Comment No. 21, 20 January 2003, E/C.12/2002/11, Ceneva.

[4] Güzeloğlu T., (2009) Küresel Gıda Krizi Ve Beslenme Hakk1, TBB Dergisi, Sayı 80.

[5] UN, Assemblée Générale, AG/10967, 28/7/2010.

[6] Manuel Pratique Pour La Réalisation Des Droits Humains À L'eau Et À L'assainissement, 2014, Portugal, http://www.ohchr.org/Documents /Issues/Water/Handbook/Book7_Principles_fr.pdf.

[7] N.U. Assemblée Générale, A/RES/64/292.

[8] N.U. Assemblée Générale, 27AG/10967, 2010.

[9] Kurt, Water rights as practice area, www.academia.edu.

[10] N.U. Rapport Annuel du Haut-Commissaire des Nations Unies A/HRC/19/34,16.12.2011.

[11] N.U., Le droit à l'eau, Fiche d'information No 35 Printed at United Nations, Geneva ISSN 1014-5605 GE.10-14426 - April 2011 - 6,775.

[12] Newspaper Sabah, http://www.sabah.com.tr/yasam/2010/07/31/

[13] Kantarc1 D., Alakır Ecological Examination on Alakır HEPP, 2011.

[14] Gülle et al., Salmo Trutta Macrostigma Population and Habitat..., University Süleyman Demirel, Journal, Vol. 4, No. 1-2, 2008.

[15] Official Gazette No. 25150 and dated 26/06/2003.

[16] Topçu E., Water Right as a Human Right, Doctoral Thesis, Ankara University Law Faculty, 2009.

[17] State Hydraulic Works, http://www.dsi.gov.tr/,22.05.2012

[18] Turkish Parliamentary Record 23.10.2014. 
[19] Yildiz, D. Last Conditions on Hydroenergy Production-2013; hhttp://www.eud.org.tr/TR/Genel/BelgeGoster.aspx?, 5.01.2014

[20] www.emlakkulisi.com/akfen-holding, 2010.

[21] Üstün B., Panel, http://dogader.org/index.php/bilgi/827-, 2012.

[22] Turkish Parliamentary Research Directorat HEPP Report 2014, www.tbmm.gov.tr.

[23] World Commission on Dams 2000, Dams and Development: A new framework for decision making, Earthscan Publ. Ltd, London, UK.

[24] Chamber of Construction Engineers Report, TMH - 471 - 2012/1.

[25] Nuran Y., Carolin H., Erkin E., Water rights and privatization in Turkey, Social Change Association, 2012.

[26] Eastern Black Sea Regional Development Plans Report (DOKAP), Vol. 5, Dpt Nippon Koei Co., Ltd. Recs International Inc, 2000, www.dokap.gov.tr.

[27] Akgedik H., Hydroelectric Power Plants in Light of Decisions of the Council of State, TAAD, Year: 4, No. 15, Oct. 2013.

[28] Islar M., Privatised Hydropower Development in Turkey: A Case of Water Grabbing? Water Alternatives 5(2): 376-391 Center of Sustainability Studies (LUCSUS) Lund University.

[29] Parallel report in response to the Initial Report by the Republic of Turkey on the Implementation of the International Covenant On Economic, Social and Cultural Rights Submission to the UN Committee on Economic, Social and Cultural Rights for its 46th Session, 2-20 May 2011.

[30] General Comments No. 15, para 48 on the right to water as well as General Comment No. 21, para 55 (e) and in the Basic Principles and Guidelines

[31] Official Gazette dated 26/9/2006 and No. 26301.

[32] Answer given to written question by The Ministry of Environment and Urban Planning answer No. 30824082-4273, dated 17.12.2013.

[33] Declaration for Another Water Policy in Turkey, Istanbul, 15. Sept. 2011. 